\title{
Efficiency of combined fodder use with reduced amount of grain in feeding lactating cows
}

\author{
V.S. Zoteev ${ }^{1, *}$, G.A. Simonov ${ }^{2}$, S.V. Zoteev ${ }^{3}$, A.V. Kirichenko ${ }^{1}$, and V.S. Nikulnikov ${ }^{4}$ \\ ${ }^{1}$ State Agrarian University, Samara, Russia \\ ${ }^{2}$ Research Center RAS, SZNIIMLPH, Vologda, Russia \\ ${ }^{3}$ NIIS - branch of SamNCRAS, Povolzhskiy, Russia \\ ${ }^{4}$ State University named after I.S. Turgenev, Oryol, Russia
}

\begin{abstract}
The assessment of the need to include combined fodder with reduced amount of grain in the diet of dairy cows by replacing it with nongrain components (wheat bran, protected fodder fat) is given. In the scientific and economic experiment on 2 groups of cows 12 heads each, the influence of combined fodder with $40 \%$ of grain components by weight on the palatability of feed, milk yield, milk composition, nutrients' digestion coefficients, biochemical blood composition, level of milk production profitability was studied. Reducing the proportion of grain to $40 \%$ in the total number of concentrate's components allows to increase $4 \%$ fat milk yield by $0.8 \%$ while increasing the amount of fat and protein by $0.02-$ $0.04 \%$. The preference for consumption per $1 \mathrm{~kg}$ of $4 \%$ fat milk was in the experimental group - 8.67 MJ ME; $337 \mathrm{~g}$ of combined fodder. Reduction of grain in the combined fodder composition contributed to an increase in profitability by $12.3 \%$.
\end{abstract}

\section{Introduction}

Currently, in our country, combined fodder for high-producing cows contains up to $60 \%$ of grain components by weight. It is possible to reduce the grain content in combined fodder for this group of animals by partially replacing it with bran, grass meal, other nongrain components. But such a replacement is accompanied by a decrease in the energy concentration in a unit of combined fodder. Therefore, high-energy non-grain components, such as "protected" feed fat should be introduced into the formulation of combined fodder $[12,21]$.

Calculations show that additives of feed fat can increase the energy nutritional content of combined fodder with a reduced grain unit mass, but such combined fodder can have a specific effect on productivity and metabolic processes in animals, in particular, it is known that feeding fats increases the risk of milk fever.

Substances that have lipotropic and ketogenic effects include methionine, choline, nicotinic acid [22].

\footnotetext{
${ }^{*}$ Corresponding author: gennadiy0007@mail.ru
} 
There are no data on the effects of complex additive of "protected" fats and "protected" methionine in the available literature, although they are of both theoretical and practical interest.

At the same time, the search is actively conducted for new grain sources being alternative to expensive and in low supply. Such crops should include sorghum. Light grained varieties of the crop in question contain no more than 0.4 tannins with antinutritional properties. In Samara region, Ros' variety white grained sorghum is used in feeding lactating cows, young cattle, broiler chickens [6].

In addition to Ros' variety grain sorghum, camelina cake was included to the diet as a replenishment source of feed protein. Its effectiveness is indicated by the results of several authors $[5,6]$.

\subsection{Purpose of research}

Identify the possibility of reducing grain consumption in the production of combined fodder for high-producing cows without reducing their full value.

The objectives of the research included:

- develop a combined fodder recipe for high-producing cows with a reduced grain amount due to the introduction of non-grain components;

- in an animal experiment, to study the combined fodder efficiency with a reduced grain amount on productivity, physiological state and metabolism of high-producing cows;

- determine the economic efficiency of experimental combined fodder use.

\section{Materials and Methods}

Cows with $6000 \mathrm{~kg}$ milk yield and the $3.7 \%$ fat mass fraction were used for the experiment. To achieve the goal, 2 groups (control and experimental) were selected on the principle of analogues (productivity, age, calving date), 12 heads per group.

In scientific and economic experiment, performing research on animals was carried out for a period of 115 days. The preliminary period of experiment lasted for 10 days, where the cows' conformity with the selected indicators using their basic diet in feeding was checked. During this period, both groups were fed with barley grain, yellow corn, feed wheat, sunflower cake as part of the combined fodder. The transition period lasted for five days, the cows of the control group were fed with the listed combined fodder ingredients; animals of the experimental group were fed with concentrated feed with reduced amount of barley, and corn and feed wheat were replaced with sorghum grain. The duration of the main period was 100 days. The experiment was conducted in accordance with the scheme:

Table 1. Experimental scheme.

\begin{tabular}{|l|c|c|}
\hline \multicolumn{1}{|c|}{ Group } & Number of heads & Feeding characteristics \\
\hline control & 12 & $\begin{array}{c}\text { Basic diet (BD) + combined fodder } \\
\text { No.1 }\end{array}$ \\
\hline experimental & 12 & BD + combined fodder No.2 \\
\hline
\end{tabular}

The main diet was the same in all groups and consisted of corn silage, alfalfa haylage, alfalfa-bromegrass hay, feed molasses. Diet balancing was carried out by combined fodder on the basis of detailed feeding standards [7]. Cows of the control group received combined fodder No.1 - KK-61. Animals of the experimental group were fed with combined fodder No. 2, which compared to fodder benchmark had $11.0 \%$ less grain part due to bran introduction; "protected" feed fat and "protected" methionine amino acid were introduced to fodder as high-energy components (Table 2). 
It should be noted that normalized and balanced diets of livestock and poultry have a beneficial effect on growth and development $[1,13,14]$, productivity, quality of products $[3,4,9-11,15-20]$, reproducibility $[2,8]$, which must be taken into account when feeding dairy cattle.

Table 2. Combined fodder composition (in \%) and nutritional value.

\begin{tabular}{|l|c|c|}
\hline \multirow{2}{*}{ Component } & \multicolumn{2}{|c|}{ Recipe } \\
\cline { 2 - 3 } & $\begin{array}{c}\text { Experimental group } \\
\text { Combined fodder No.2 }\end{array}$ & $\begin{array}{c}\text { Control group } \\
\text { Combined fodder No.1 }\end{array}$ \\
\hline Sorghum & 30.0 & - \\
\hline Barley & 10.0 & 15.0 \\
\hline Yellow corn & - & 20.0 \\
\hline Wheat bran & 20.0 & 20.0 \\
\hline Feed wheat & - & 16.0 \\
\hline "Protected" fat & 3.0 & - \\
\hline "Protected" methionine & 0.3 & - \\
\hline Camelina cake & 15.0 & - \\
\hline Feed gluten & 12.7 & 10.0 \\
\hline Sunflower cake & - & 15.0 \\
\hline Beet molasses & 5.0 & 1.0 \\
\hline Premix P 60-3 & 1.0 & 1.0 \\
\hline Defluorinated phosphate & 1.0 & 1.0 \\
\hline Monocalcium phosphate & 1.0 & 1.0 \\
\hline Sodium chloride & 1.0 & 100.0 \\
\hline Total & 100.0 & \\
\hline 1 kg contains: & & 110.2 \\
\hline Metabolic energy, MJ & 106.0 & 205.0 \\
\hline Crude protein, g & 207.0 & \\
\hline
\end{tabular}

Accounting of dairy productivity was carried out every decade. The mass fraction content of protein and fat was determined once a month.

Balance experiment was carried out to calculate the coefficients of diet nutrients' digestion by experimental cows. To determine the economic indicators of the feasibility of experimental combined fodder diet inclusion, all costs were considered.

\section{Results and Discussion}

Based on the account of consumed fodder, it was concluded that the rations complied with detailed feeding standards of dairy cows (Table 3).

Table 3. Average daily diet.

\begin{tabular}{|l|c|c|}
\hline \multirow{2}{*}{\multicolumn{1}{|c|}{ Indicator }} & \multicolumn{2}{c|}{ Group } \\
\cline { 2 - 3 } & experimental & control \\
\hline Alfalfa haylage, $\mathrm{kg}$ & 12.9 & 12.6 \\
\hline Corn silage, kg & 18.9 & 18.3 \\
\hline Alfalfa-bromegrass hay, $\mathrm{kg}$ & 2.3 & 2.1 \\
\hline Beet molasses, kg & 1.3 & 1.3 \\
\hline Combined fodder, kg & 8.15 & 8.14 \\
\hline Contains: & & \\
\hline EFU: & 20.98 & 20.97 \\
\hline Crude protein, g & 3498 & 3444 \\
\hline Dry matter, kg & 20.3 & 20.0 \\
\hline Digestible protein, g & 2378 & 2341 \\
\hline Crude fiber, g & 4186 & 4049 \\
\hline Sugar, g & 1339 & 1312 \\
\hline
\end{tabular}




\begin{tabular}{|l|c|c|}
\hline Starch, g & 5106 & 4884 \\
\hline Sugar-protein ratio & 0.6 & 0.6 \\
\hline
\end{tabular}

Dairy productivity and milk quality are indicators of diets' completeness (Table 4).

Table 4. Productivity of cows on average per head.

\begin{tabular}{|l|c|c|}
\hline \multirow{2}{*}{ Indicator } & \multicolumn{2}{c|}{ Group } \\
\cline { 2 - 3 } & Experimental & Control \\
\hline Average liquid milk yield, $\mathrm{kg}$ & $25.2 \pm 0.08$ & $25.1 \pm 0.02$ \\
\hline $\begin{array}{l}\text { Average daily milk yield 4\% } \\
\text { fat content, } \mathrm{kg}\end{array}$ & $24.2 \pm 0.73$ & $24.0 \pm 0.24$ \\
\hline Content in milk, \% & & \\
\hline fat & $3.84 \pm 0.06$ & $3.82 \pm 0.02$ \\
\hline protein & $3.19 \pm 0.07$ & $3.15 \pm 0.03$ \\
\hline $\begin{array}{l}\text { Content of somatic cells, } \\
\text { thousand/cm }\end{array}$ & $280 \pm 119$ & $285 \pm 135$ \\
\hline $\begin{array}{l}\text { Costs per 1 kg milk with 4\% } \\
\text { fat content: }\end{array}$ & & \\
\hline Metabolic energy, MJ & 8.67 & 8.74 \\
\hline Dry matter, g & 840 & 830 \\
\hline Crude protein, g & 145 & 143 \\
\hline Combined fodder, g & 337 & 339 \\
\hline
\end{tabular}

As can be seen from the data of table 4, the average daily liquid milk yield during the research period of the experimental group cows exceeded control by $0.4 \%$. They had a slightly higher fat content, which resulted in the average daily milk yield adjusted by $4.0 \%$ fat content being higher in cows of the experimental group by $0.8 \%$.

For the experimental period, the cows of the experimental group consumed $8.67 \mathrm{~mJ}$ of exchange energy, to produce $1 \mathrm{~kg}$ of $4.0 \%$ fat milk, which is $0.8 \%$ less compared to the animals of the control group.

Similar results were obtained on the costs of dry matter, crude protein, and combined fodder.

Table 5. Nutrient digestion coefficients.

\begin{tabular}{|l|c|c|}
\hline \multirow{2}{*}{\multicolumn{1}{|c|}{ Indicator }} & \multicolumn{2}{c|}{ Group } \\
\cline { 2 - 3 } & Experimental & Control \\
\hline Digestibility, \%: & & \\
\hline Dry matter & $65.3 \pm 0.4$ & $62.7 \pm 1.4$ \\
\hline organic matter & $67.1 \pm 1.9$ & $64.9 \pm 1.2$ \\
\hline protein & $73.8 \pm 1.3$ & $69.1 \pm 1.1$ \\
\hline fat & $66.2 \pm 0.3$ & $65.6 \pm 1.1$ \\
\hline fiber & $55.2 \pm 1.0$ & $49.9 \pm 1.9$ \\
\hline NFES & $75.3 \pm 0.9$ & $70.4 \pm 0.3$ \\
\hline Stored in the body, g: & & \\
\hline calcium & $14.0 \pm 3.8$ & $13.2 \pm 4.1$ \\
\hline phosphorus & $4.9 \pm 0.4$ & $4.7 \pm 0.2$ \\
\hline nitrogen & $3.7 \pm 1.6$ & $3.1 \pm 1.4$ \\
\hline $\begin{array}{l}\text { Used from received, } \\
\text { \% }\end{array}$ & & \\
\hline calcium & 35.3 & 31.1 \\
\hline phosphorus & 31.0 & 28.0 \\
\hline nitrogen & 32.4 & 31.2 \\
\hline
\end{tabular}

Table 5 data show a trend towards slightly better digestion of diet nutrients by animals of the experimental group. Positive calcium and phosphorus balance was observed in all 
groups. The best indicators were noted in the animals of the control group receiving benchmark fodder in the diet, although in absolute quantities the highest deposition of these elements was in experimental group's animals.

Nitrogen balance was positive across all groups. Combined fodder No. 2 with a reduced level of grain components did not have a negative effect on nitrogenous metabolism in animals of the experimental group.

Statistically significant differences in the concentration of metabolites of nitrogenous, carbohydrate and fat metabolism in animals of control and experimental groups were not revealed by biochemical studies [23].

When calculating the economic indicators of non-grain ingredients' use, the profitability level of $1 \mathrm{cwt}$ milk production in the experimental group compared to the control was higher by $12.3 \%$.

\section{Conclusions}

Milk productivity of cows has not undergone negative changes when feeding combined fodder with reduced grain content.

Reduction of the grain feed share by $11.0 \%$ by mass due to the inclusion of "protected" fat, "protected" methionine, feed molasses allowed to increase diet nutrients digestibility of the experimental group cows compared to the animals of the control group.

Statistically significant differences in the concentration of metabolites of nitrogenous, carbohydrate and fat metabolism in animals of control and experimental group have not been revealed by biochemical studies.

The best milk production efficiency was established when using combined fodder with a reduced amount of grain against the background of a silage-hay diet in the high-producing cows' diet.

Compared to animals of the control group, the profitability level of experimental group was higher by $12.3 \mathrm{abs} . \%$.

\section{References}

1. D. Gayirbegov, Poultry farming, 1, 23 (2008)

2. D. Gayirbegov, Pig breeding, 1, 10 (2009)

3. D. Gayirbegov, Combined fodder, 12, 63 (2015)

4. V.S. Zoteev, Animal husbandry, 5, 45 (1985)

5. V.S. Zoteev, Sheep, goats, wool business, 1, 29 (2014)

6. S.V. Zoteev, V.S. Zoteev, G.A. Simonov, V.V. Mukhranov, Poultry industry, 6, 27 (2017)

7. A.P. Kalashnikov, Animal husbandry, 9, 7 (1984)

8. A.P. Kalashnikov, Papers of the All-Union Academy of Agricultural Sciences named after Lenin, 11, 29 (1984)

9. V.V. Mungin, Poultry farming, 7, 31 (2016)

10. I.V. Serebrova, Achievements of science and technology of AIC, 1, 48 (2011)

11. G. Simonov, Dairy and beef cattle breeding, 4, 19 (2011)

12. A.P. Taranovich, Dairy and meat cattle breeding, 4, 18 (2010)

13. E.A. Tyapugin, Pig breeding, 1, 18 (2011)

14. E.A. Tyapugin, Russian agricultural science, 2, 52 (2018) 
15. A. Ushakov, V. Epifanov, A. Mikityuk, Combined fodder, 12, 81 (2016)

16. A. Fedin, Poultry farming, 8, 17 (2006)

17. A. Fedin, Poultry farming, 9, 24 (2006)

18. A. Fedin, Poultry farming, 8, 26 (2011)

19. A. Shaposhnikov, Poultry farming, 4, 41 (2009)

20. I. Yapparov, Poultry farming, 9, 20 (2006)

21. U. Moallem, M. Kate, H. Lehrer, L. Livshitz, S. Yakoby, J. Lairy Sci., 90, 1243 (2007)

22. L. Pinotti, A. Baldi, J. Politis, R. Rebucci, L. Sangalli, V. Dell Orto, J.Vet.Med, 50, 18 (2003)

23. A. T. Varakin, D. K. Kulik, V. V. Salomatin, V. S. Zoteev, G. A. Simonov, International Journal of Innovative Technology and Exploring Engineering (IJITEE), 9(1), 3837 (2019) 